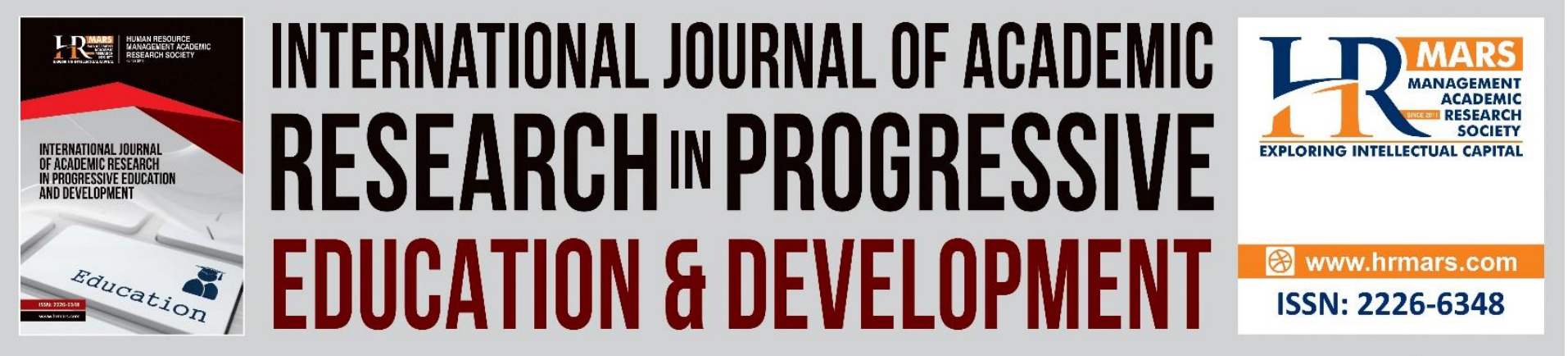

\title{
Critical Competency Attributes of Technical and Vocational Education and Training (TVET) Postgraduate Students in Online Learning Environment
}

Muhd Khaizer Omar, Ding Meng Jie, Mohd Hazwan Mohd Puad \& Normala Ismail

To Link this Article: http://dx.doi.org/10.6007/IJARPED/v11-i1/12124 DOI:10.6007/IJARPED/v11-i1/12124

Received: 09 November 2021, Revised: 16 December 2021, Accepted: 28 December 2021

Published Online: 25 January 2022

In-Text Citation: (Omar et al., 2022)

To Cite this Article: Omar, M. K., Jie, D. M., Puad, M. H. M., \& Ismail, N. (2022). Critical Competency Attributes of Technical and Vocational Education and Training (TVET) Postgraduate Students in Online Learning Environment. International Journal of Academic Research in Progressive Education and Development, 11(1), 428-447.

Copyright: (C) 2022 The Author(s)

Published by Human Resource Management Academic Research Society (www.hrmars.com)

This article is published under the Creative Commons Attribution (CC BY 4.0) license. Anyone may reproduce, distribute, translate and create derivative works of this article (for both commercial and non-commercial purposes), subject to full attribution to the original publication and authors. The full terms of this license may be seen at: http://creativecommons.org/licences/by/4.0/legalcode

Vol. 11(1) 2022, Pg. 428 - 447

http://hrmars.com/index.php/pages/detail/IJARPED

JOURNAL HOMEPAGE

Full Terms \& Conditions of access and use can be found at http://hrmars.com/index.php/pages/detail/publication-ethics 


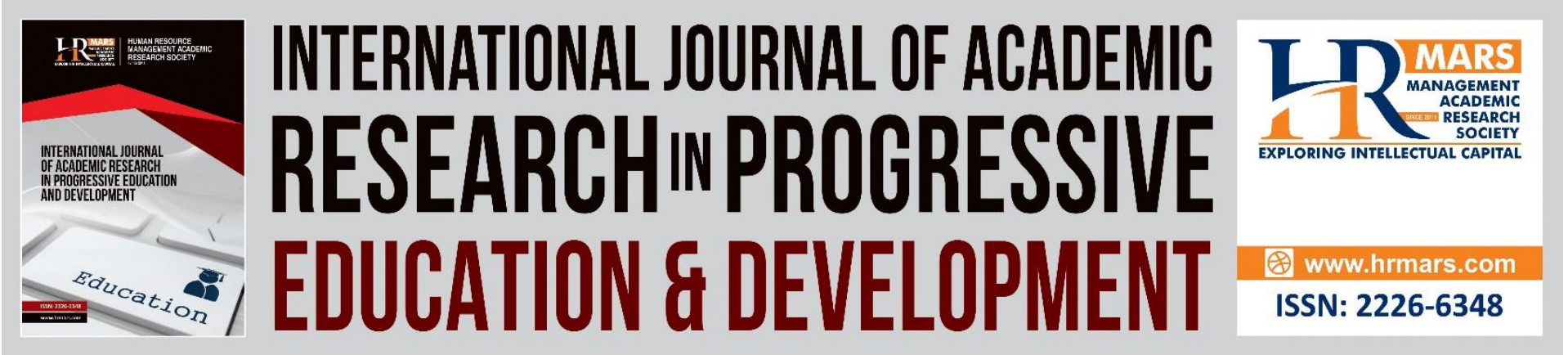

\title{
Critical Competency Attributes of Technical and Vocational Education and Training (TVET) Postgraduate Students in Online Learning Environment
}

\author{
Muhd Khaizer Omar, Ding Meng Jie, Mohd Hazwan Mohd \\ Puad \& Normala Ismail \\ Department of Science and Technical Education Faculty of Educational Studies \\ Universiti Putra Malaysia \\ Email: khaizer@upm.edu.my
}

\begin{abstract}
Student competency has become the central agenda in graduates' employability. Reflecting on the overarching situation of COVID-19 pandemic, students have been compelled to acquire knowledge using online platforms, conjecturing the competency attributes being left out from conventional teaching and learning environments. This paper examines the development of competency attributes: knowledge, skills, and attitudes, which were selected as main variables. A correlation analysis was performed to obtain the results of the relationship between the competency attributes and the online learning environment. There were 70 postgraduate students, randomly selected as samples of the study. The discussion of the results centered on the competency attributes developed by the students and their relationships with the online learning environment. The implications for educational stakeholders based on the findings are further discussed.
\end{abstract}

Keywords: Knowledge, Skill, Attitude, Student Competency, TVET, Online Learning

\section{Introduction}

The Technical and Vocational Education and Training (TVET) system galvanizes training-based learning experiences in theoretical and practical forms in efforts to provide skilled employees before entering the workforce. Empowering added values and employment marketability of graduates becomes the premise of the TVET system in penetrating the development of human capital in the challenging job market (Dlamini, 2015). TVET serves to provide a platform to train graduates with technical skills and technological knowledge in line with current industrialization developments. TVET educates people from a variety of industries, such as engineering, accounting, nursing, and law which most are based on manual or practical activities and are related to a particular industry, occupation, or vocational (Ladipo, Akhuemonkhan \& 
Raimi, 2013). With the utmost intention, TVET is hoped to produce ready-made graduates for local and global employment thus expanding job opportunities for grassroots.

Reflecting on the challenges of the learning ecosystem due to the impact of COVID19, the TVET system struggles in meeting up the industry demands on graduates' competency (Bilsland et al., 2020). In the present situation, the teaching and learning environment has been conducted in a fully online learning mode in most TVET institutions. This condition is conflicting with the pragmatic approach of the TVET system where hands-on mastery and practical skills are necessary (Omar et al., 2020). Speaking of that, the graduates competency in TVET, particularly, demanding continuous training via physical classroom arrangement.

The current trend shows that students are more engaging in online learning rather than conventional learning methods. With the establishment of Massive Open Online Courses (MOOCs) and micro-credential courses, learning environments have shifted into a new era. Kotler et al (2005), on top of that, espoused that Internet technology has transformed traditional learning to online education, which also impacts TVET learning. Online learning environments allow an educator to have a better class by providing students with individual activities that can meet their characteristics and fulfill their needs. Technological capabilities help and influence accelerating online learning. As the internet becomes more and more prevalent in individuals' life, it is vital to have real interpersonal communication, both from industrial perspectives and TVET institutions to integrate educational values and knowledge content from the curriculum (Grdic et al., 2008).

It is inevitable that presently, individuals can engage in social activities, entertainment, learning, and numerous activities via the use of internet technology at home. The Internet is a window for college students to explore the outside world. Students adapt to new forms of communication and knowledge-seeking through the internet. Complementary to this, the TVET online education program at the location of the study adopted the identical curriculum as to the traditional teaching approach and employed a full-time program on a semester basis. The lecturers are required to regulate the same learning outcomes and commitment similar to full-time face-toface courses. The growth in online learning methods has prompted this research to be conducted due to differences with face-to-face learning methods. The TVET online learning course was launched remotely. A few questions were asked about the competency traits of the students who undergo the learning process that brings to the needs of this research. This research aims to determine the competency attributes developed by students via online learning ecosystems among TVET postgraduate students in UPM. In addition, this study signifies the crucial agenda in TVET transformation plan on the new qualifications and competencies framework (UNESCO-UNEVOC, 2021). The competency attributes motivates TVET stakeholders at any educational levels to improve curriculum and training modules by aligning the 
published framework. This whole agenda will be more likely transform TVET education to be more vibrant and industrial-driven.

\section{Literature Review}

In the past years, graduate competency has attracted much attention among researchers and become the main concern among educational stakeholders. The pertinent facts from the research findings indicated vital contributions of understanding student competency based on their learning experiences. Boyatzis (1982); Mathur et al (1998) described competency as a composure of knowledge attributes (cognitive), skills (psychomotor), practical understandings, and attitudes (affective domains such as motivation and personality) are shown in behavior forms when doing something. Knowledge and skills are "superficial" and therefore observable and measurable (Kock \& Elleström, 1997; Robotham \& Jubb, 1996). Personality and motivation are deeply rooted in the heart of a person and are often associated with more enduring personality traits. Self-concept is a concept between personal attitude, values, and self-image. The main purpose of identifying competence is to define standards of behavior in the workplace (Yonghak, 2009).

Theoretically, when the materials learned are considered useful and relevant to a person's needs, and the individual thinks he or she will be skilled at performing the task on his or her own, the level of knowledge will be improved (Keller, 1979). However, online education about students' competency traits in TVET education is kind of missing, less scholars talk about students' competency traits with online education, most of them talk about teachers' competency traits.

\section{Knowledge Competency Attribute}

Knowledge is thought of as the concrete manifestation of abstract intelligence, however, the result of the interaction between intelligence (the ability to learn) and environment (the opportunity to learn), is more social than intelligence. Knowledge includes theoretical knowledge, conceptual knowledge, and tacit knowledge. Tacit knowledge is knowledge acquired in the process of completing certain tasks. Understanding refers to a more comprehensive understanding of the process and environment, and can be distinguished as knowing why rather than knowing that. Therefore, each level of knowledge and learning depends on the basic mental ability, which implies the general learning transferability and the assumption of knowledge acquisition logic. In all fields, there is a logic that cognitive premises and specific knowledge need to be satisfied by acquiring and understanding new knowledge of skills. Knowledge and skills are usually inseparable in typology because of the interaction between them. Klieme (2004) argue that higher levels of competence are characterized by an increasing degree of the routinization of knowledge, so that at a higher level, knowledge is translated into skill. Previous research in distance learning has more focus on learning style (Roberts \& Dyer, 2005). The learning style and cognitive style terminology are used interchangeably in research (James \& Gardner, 1995). They further defined learning style as an individual learner react to learning environment generally. 
In addition, Collin (1997) cites Gardner's association of know-how with tacit knowledge and know-that with propositional knowledge. Another way of expressing this distinction is between declarative knowledge (knowing what) and procedural knowledge (knowing how). From this perspective, it is often argued that acquiring declarative knowledge (explicit factual knowledge) must precede developing procedural knowledge, which relates to utilizing knowledge in context. According to Schunk (2000), an individual has their own style of absorbing, processing, and retain an information. In this study, TVET students have various learning styles due to their knowledge competency perceived in their online learning environment.

\section{Skill Competency Attribute}

Welford (1968) defined skill as a combination of factors for competent, professional, rapid and accurate performance, which he believed also applies to manual and intellectual activities. Welford's $(1968 ; 1976)$ work focus on sensorimotor performance, and because the two are closely related in practice, this is true of many skill studies (Fuchs, 1962; Lintern \& Gopher, 1978). Welford's work demonstrates how to select and coordinate actions at different levels of skill performance, as well as practices and training conditions that facilitate skill acquisition and transfer.

Recently, a wide range of cognitive skills, such as problem-solving and decision making, has been increasingly taken into account in the study of skill performance. Welford (1968) demonstrates the difficulty of treating cognitive abilities as knowledge rather than skills. There is considerable evidence that the acquisition of skills and the display of professional skills have much to do with the underlying combination of perceptual, cognitive, and motor skills (Carlson \& Yaure, 1990; Salthouse, 1986). Besides, keeping motor skills relatively simple seems to depend on the understanding of results (Lavery, 1962) and oral knowledge (Berry \& Broadbent, 1988), or the knowledge elaborated in developing these skills. Also, knowledge and working memory play important roles in acquiring skills (Chase \& Ericsson, 1982), as well as programming skills (Carlson, Sullivan \& Schneider, 1989), problem-solving skills (Carlson \& Yaure, 1990), and complex cognitive skills (Logie et al., 1989; McKeithen et al., 1981).

\section{Attitude Competency Attribute}

Attitudes are not innate. They are formed gradually through the process of self and socialization, and at the same time in the acquired living environment. The formation of attitude is often closely related to desire. Second, as a cognitive component of experience and attitude, it is closely related to one's knowledge. The third is a personal experience. The accumulation and differentiation of experience will gradually form many attitudes in the practice of life. Social psychologists believe that attitudes have strong emotional color, it is different from the general cognitive activities, once formed will be more stable, lasting, and not easy to manipulate. As for the theory of attitude formation, the social psychologist Kelman (1974) proposed three stages of attitude formation: obedience, assimilation, and internalization. 
Attitude is people's evaluation and behavior tendency of things based on their morality and values. Attitude is embodied in the three components of inner feeling, emotion, and intention towards external things. Any of the expressive attributes in the stimulation of attitude will trigger the corresponding response of the other two attributes: the coordination and consistency of the three attributes of feeling, emotion, and intention. Generally speaking, the components of an attitude are in harmony with each other. Still, when they are not in harmony, the emotional component often occupies a dominant position, determining the attitude's basic orientation and behavioral tendency.

The psychological structure of attitude mainly includes three factors: cognitive factor, affective factor, and intention factor. Cognitive factor refers to the meaning of an individual's evaluation of attitude object. The narrative content includes a personal understanding of attitude, trust and doubt, approval or disapproval, and other emotional factors. The affective factor is the experience of an individual's emotional attitude toward the object of his or her affection, as respect versus contempt, compassion versus indifference, love versus hate, and so on. The third is the intention factor. The intention factor refers to the behavioral state of the individual's reaction tendency or preparation to the object of attitude, that is, the individual's reaction to the object. According to social psychology, attitude refers to an individual's evaluative and stable internal psychological tendency when he/she responds to a particular object in a certain way.

Figure 1. Conceptual Framework

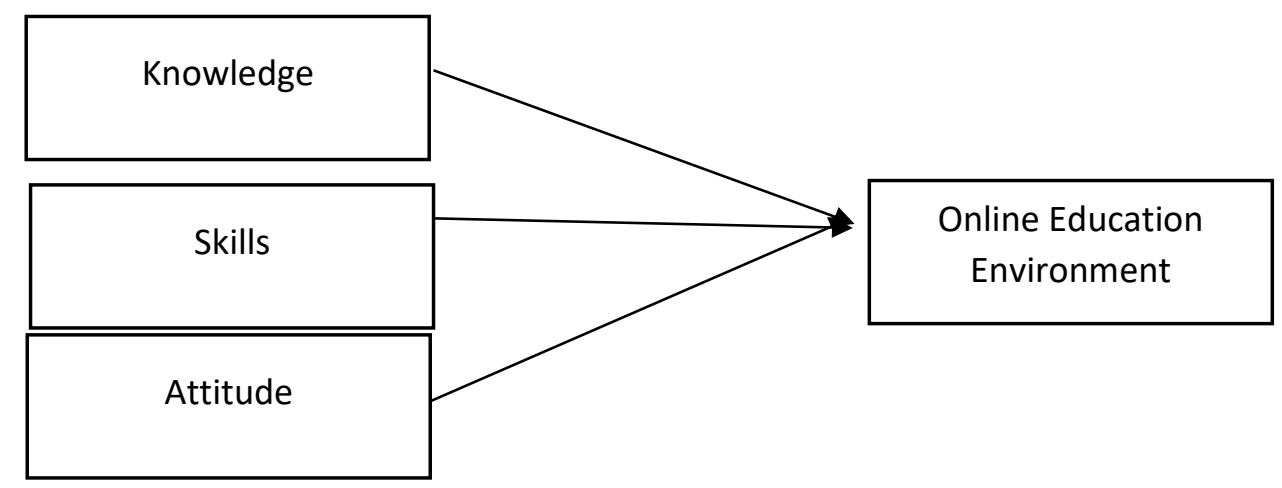

As discussed, competency traits have three categories which are knowledge, skills, attitude. In this study, competency traits are employed as independent variables. The online education environment is the dependent variable. In summary, the researchers describe each attribute of competency-based on theoretical literature and provide a conceptual framework to illustrate the relationships of the studied variables (see Figure 1).

\section{Methodology}

In this study, a quantitative correlational study was employed to obtain the respondents' information as it enables the generalization of the findings from the 
sample to the population interest. According to Creswell and Creswell (2018), a quantitative method is an approach for testing assumptions and objective theories by testing the correlation between the variables. The respondents for this research were TVET postgraduate students of UPM. Eighty respondents were involved and randomly selected based on Yamane's formula on calculating sample size with a total population of 100 from postgraduate students registered in the Master of Education in TVET program at Faculty of Educational Studies, UPM. In this research, the questionnaire was self-constructed based on the research question of this study. The questionnaire was first validated by two TVET lecturers and piloted before the actual study. The results of the Cronbach Alpha are described in Table 1:

Table 1. Cronbach's Alpha Value for Variables

\begin{tabular}{clcc} 
Section & Variable & Number of items & Cronbach's Alpha Value \\
B & Knowledge & 14 & 0.793 \\
C & Skills & 13 & 0.704 \\
D & Attitude & 16 & 0.840 \\
E & Online learning Ecosystem & 8 & 0.820 \\
\hline
\end{tabular}

The questionnaires consisted of five sections. Section A was about the demographic of the respondents, the questions were focused on the demographic profile of respondents such as gender, age, race, current cumulative grade point average (CGPA), and type of student. Section B is purposely to measure the knowledge that students received. Section $C$ is about what skills students want to learn. In section $D$, the attitude of the student, how they think about the online course. Section $E$ is about the online learning environment. The total number of questions is 56 questions. The estimated duration to answer is 20 minutes. The descriptive analysis and Pearson Correlation were employed to analyze the data. Pearson Correlation is used to study the correlation between the independent variables and the dependent variable. By determining the correlation between each other, the relationship between the variables can be identified whether there is any correlation exists among studied variables.

\section{Results}

\section{Demographic Factor}

The data analysis was carried out using descriptive analysis including percentage, mean score, and standard deviation. In defining the respondent's demographics factor, gender, age, race, CGPA and type of student were asked in the survey. Table 2 showed the result of the analysis of demographic data that includes gender, age, race, current cumulative grade point average (CGPA) of respondents' demographics according to each factor. A total of 70 respondents answered the survey $(87.5 \%$ response rate. 
Table 2: Demographic Profile of the Respondents

\begin{tabular}{llll}
\hline Variable & Category & Frequency & Percentage \\
Gender & Male & 16 & $22.9 \%$ \\
Age & Female & 54 & $77.1 \%$ \\
& $20-25$ & 25 & $35.7 \%$ \\
& $25-30$ & 36 & $51.4 \%$ \\
Race & $30-35$ & 4 & $5.7 \%$ \\
& Above 35 & 5 & $7.1 \%$ \\
Current CGPA & Malay & 65 & $92.9 \%$ \\
Type of student & Chinese & 2 & $2.9 \%$ \\
& Others & 3 & $4.3 \%$ \\
& Full-time & 48 & $100 \%$ \\
& Part-time & 22 & $68.6 \%$ \\
& Total & 70 & $31.4 \%$ \\
\hline
\end{tabular}

Knowledge, Skills, Attitude, and Online Learning Environment Descriptive Findings Table 3 describes the descriptive analysis on the variables: knowledge, skills, attitude, and online learning environment. The items that described the highest mean were highlighted in bold (see table 3). The highest means of the competency attributes of knowledge is "I ask myself questions about what I am going to learn before I begin to learn for the online course" $(M=3.83, S D=0.761)$. Next, the item that depicts the highest mean for skills aspect is "I always look up the skills that I want to learn on the Internet" with $\mathrm{M}=3.81$ and $\mathrm{SD}=0.748$ respectively. Two items shared the similar highest mean values, "I manage to keep working on my task in the online course until I finish" (M=3.84, $S D=0.895)$ and "I check with other people to make sure about the materials in the online course" $(M=3.84, S D=0.792)$ sequentially. The data for the online learning environment was collected as a dependent variable (see figure1) to determine the relationship of the competency attributes with the condition of the learning. The highest mean shows that the aspect of "I choose the location where I study for the online course to avoid too much distraction" ( $M=3.81, S D=0.728)$ becomes the preferable condition factor to describe the most viable condition of an online learning environment for the students. 
Table 3. Descriptive Analysis on the Variables: Knowledge, Skills, Attitude, and Online Learning Environment $(n=70)$

\begin{tabular}{|c|c|c|c|c|c|c|c|c|c|c|c|}
\hline \multicolumn{3}{|c|}{ Knowledge } & \multicolumn{3}{|c|}{ Skills } & \multicolumn{3}{|c|}{ Attitude } & \multicolumn{3}{|c|}{ Online Learning Environment } \\
\hline Item & $\mathbf{M}$ & S.D & Item & $\mathbf{M}$ & S.D & Item & M & SD & Item & M & SD \\
\hline $\begin{array}{l}\text { I learn on } \\
\text { projects during } \\
\text { online learning }\end{array}$ & 3.70 & 0.805 & $\begin{array}{l}\text { I use computer } \\
\text { and information } \\
\text { technology to } \\
\text { learn more skills }\end{array}$ & 3.56 & 0.958 & $\begin{array}{l}\text { Online } \\
\text { education is } \\
\text { more } \\
\text { effective } \\
\text { than } \\
\text { traditional } \\
\text { education }\end{array}$ & 3.71 & 0.801 & $\begin{array}{l}\text { I prefer to study } \\
\text { at home during } \\
\text { online education }\end{array}$ & 3.71 & 0.725 \\
\hline $\begin{array}{l}\text { I gain } \\
\text { knowledge } \\
\text { from the } \\
\text { lecture in the } \\
\text { online learning }\end{array}$ & 3.69 & 0.941 & $\begin{array}{l}\text { I ask myself } \\
\text { questions about } \\
\text { skills I want to } \\
\text { learn while } \\
\text { learning in the } \\
\text { online course. }\end{array}$ & 3.76 & 0.751 & $\begin{array}{l}\text { I prefer to } \\
\text { use online } \\
\text { education. }\end{array}$ & 3.71 & 0.783 & $\begin{array}{l}\text { I usually stay with } \\
\text { my classmates } \\
\text { during online } \\
\text { education. }\end{array}$ & 3.80 & 0.714 \\
\hline $\begin{array}{l}\text { I have received } \\
\text { a lot of } \\
\text { knowledge } \\
\text { during the } \\
\text { online learning }\end{array}$ & 3.74 & 0.896 & $\begin{array}{l}\text { 3. I am aware of } \\
\text { skills in the } \\
\text { future when I } \\
\text { study through } \\
\text { an online } \\
\text { course. }\end{array}$ & 3.79 & 0.700 & $\begin{array}{l}\text { I have more } \\
\text { motivation to } \\
\text { learn through } \\
\text { online } \\
\text { learning }\end{array}$ & 3.67 & 0.812 & $\begin{array}{l}\text { I have an } \\
\text { appropriate } \\
\text { network for me } \\
\text { to use online } \\
\text { course }\end{array}$ & 3.44 & 0.862 \\
\hline $\begin{array}{l}\text { I use an } \\
\text { electronic } \\
\text { medium(e.g.: } \\
\text { chat group, } \\
\text { internet, etc.) } \\
\text { to complete }\end{array}$ & 3.60 & 0.824 & $\begin{array}{l}\text { When I register } \\
\text { for an online } \\
\text { course, I will } \\
\text { always think } \\
\text { about what } \\
\text { skills I have }\end{array}$ & 3.70 & 0.823 & $\begin{array}{l}\text { I spend more } \\
\text { time online } \\
\text { than } \\
\text { traditional } \\
\text { learning }\end{array}$ & 3.79 & 0.866 & $\begin{array}{l}\text { I choose the } \\
\text { location where I } \\
\text { study for an } \\
\text { online course to } \\
\text { avoid too much } \\
\text { distraction. }\end{array}$ & 3.81 & 0.728 \\
\hline
\end{tabular}


INTERNATIONAL JOURNAL OF ACADEMIC RESEARCH IN PROGRESSIVE EDUCATION AND DEVELOPMENT

Vol. 11, No. 1, 2022, E-ISSN: 2226-6348 @ 2022 HRMARS

\begin{tabular}{|c|c|c|c|c|c|c|c|c|c|c|c|}
\hline $\begin{array}{l}\text { the } \\
\text { assignment }\end{array}$ & & & $\begin{array}{l}\text { learned after I } \\
\text { finish working } \\
\text { on this online } \\
\text { course. }\end{array}$ & & & & & & & & \\
\hline $\begin{array}{l}\text { I use an e-mail } \\
\text { to } \\
\text { communicate } \\
\text { with a lecture } \\
\text { (e.g: } \\
\text { assignment, } \\
\text { projects ) }\end{array}$ & 3.63 & 0.871 & $\begin{array}{l}\text { I try to use skills } \\
\text { in the past in } \\
\text { online courses. }\end{array}$ & 3.60 & 0.750 & $\begin{array}{l}\text { I set goals to } \\
\text { help me } \\
\text { manage my } \\
\text { studying time } \\
\text { for an online } \\
\text { course. }\end{array}$ & 3.57 & 0.972 & $\begin{array}{l}\text { I find a } \\
\text { comfortable } \\
\text { place to study for } \\
\text { an online course. }\end{array}$ & 3.59 & 0.789 \\
\hline $\begin{array}{l}\text { I always look } \\
\text { up information } \\
\text { that I do not } \\
\text { understand } \\
\text { from the } \\
\text { Internet }\end{array}$ & 3.60 & 0.923 & $\begin{array}{l}\text { I think about } \\
\text { skills I need to } \\
\text { learn before I } \\
\text { begin a task in } \\
\text { this online } \\
\text { course. }\end{array}$ & 3.73 & 0.900 & $\begin{array}{l}\text { I keep up } \\
\text { with the } \\
\text { weekly } \\
\text { readings and } \\
\text { assignments } \\
\text { for an online } \\
\text { course. }\end{array}$ & 3.83 & 0.884 & $\begin{array}{l}\text { I know where I } \\
\text { can study most } \\
\text { efficiently for an } \\
\text { online course. }\end{array}$ & 3.67 & 0.812 \\
\hline $\begin{array}{l}\text { I discuss ideas } \\
\text { from readings } \\
\text { with others } \\
\text { online }\end{array}$ & 3.73 & 0.916 & $\begin{array}{l}\text { Before taking } \\
\text { the online } \\
\text { course, I ask } \\
\text { myself skills I } \\
\text { get once I'm } \\
\text { finished working } \\
\text { on this online } \\
\text { course. }\end{array}$ & 3.66 & 0.778 & $\begin{array}{l}\text { I know what } \\
\text { the lecture } \\
\text { expects me } \\
\text { to learn in an } \\
\text { online } \\
\text { course. }\end{array}$ & 3.76 & 0.859 & $\begin{array}{l}\text { I have a regular } \\
\text { place set aside for } \\
\text { studying for this } \\
\text { online course. }\end{array}$ & 3.77 & 0.705 \\
\hline
\end{tabular}




\begin{tabular}{|c|c|c|c|c|c|c|c|c|c|c|c|}
\hline $\begin{array}{l}\text { I am aware of } \\
\text { what } \\
\text { knowledge I } \\
\text { learn when I } \\
\text { study for an } \\
\text { online course. }\end{array}$ & 3.57 & 0.791 & $\begin{array}{l}\text { I will analyze the } \\
\text { use of skills } \\
\text { while I study for } \\
\text { this online } \\
\text { course. }\end{array}$ & 3.71 & 0.663 & $\begin{array}{l}\text { I manage to } \\
\text { keep } \\
\text { working on } \\
\text { my task in } \\
\text { the online } \\
\text { course until I } \\
\text { finish. }\end{array}$ & 3.84 & 0.895 & $\begin{array}{l}\text { I have a laptop or } \\
\text { computer for me } \\
\text { to learn online }\end{array}$ & 3.63 & 0.765 \\
\hline $\begin{array}{l}\text { I ask myself } \\
\text { questions } \\
\text { about how } \\
\text { much } \\
\text { knowledge I } \\
\text { received while } \\
\text { learning in the } \\
\text { online course }\end{array}$ & 3.60 & 0.824 & $\begin{array}{l}\text { I discuss the } \\
\text { skills that I am } \\
\text { not familiar with } \\
\text { others through } \\
\text { online }\end{array}$ & 3.67 & 0.793 & $\begin{array}{l}\text { I am } \\
\text { persistent in } \\
\text { getting help } \\
\text { from the } \\
\text { lectures of } \\
\text { online course }\end{array}$ & 3.71 & 0.837 & & & \\
\hline $\begin{array}{l}\text { I think about } \\
\text { the knowledge } \\
\text { I have learned } \\
\text { after an online } \\
\text { course. }\end{array}$ & 3.47 & 0.756 & $\begin{array}{l}\text { I always look up } \\
\text { the skills that I } \\
\text { want to learn } \\
\text { on the internet. }\end{array}$ & 3.81 & 0.748 & $\begin{array}{l}\text { I } \\
\text { communicate } \\
\text { with my } \\
\text { classmates to } \\
\text { find out how } \\
\text { I am doing in } \\
\text { an online } \\
\text { course. }\end{array}$ & 3.74 & 0.912 & & & \\
\hline $\begin{array}{l}\text { I share my } \\
\text { problems with } \\
\text { my classmates } \\
\text { in the course } \\
\text { online so we }\end{array}$ & 3.60 & 0.824 & $\begin{array}{l}\text { I use an app } \\
\text { (e.g.: } \\
\text { Dreamweaver, } \\
\text { YouTube, etc.) } \\
\text { to learn the }\end{array}$ & 3.71 & 0.783 & $\begin{array}{l}\text { I check with } \\
\text { other people } \\
\text { to make sure } \\
\text { about the } \\
\text { materials in }\end{array}$ & 3.84 & 0.792 & & & \\
\hline
\end{tabular}


INTERNATIONAL JOURNAL OF ACADEMIC RESEARCH IN PROGRESSIVE EDUCATION AND DEVELOPMENT

Vol. 11, No. 1, 2022, E-ISSN: 2226-6348 @ 2022 HRMARS

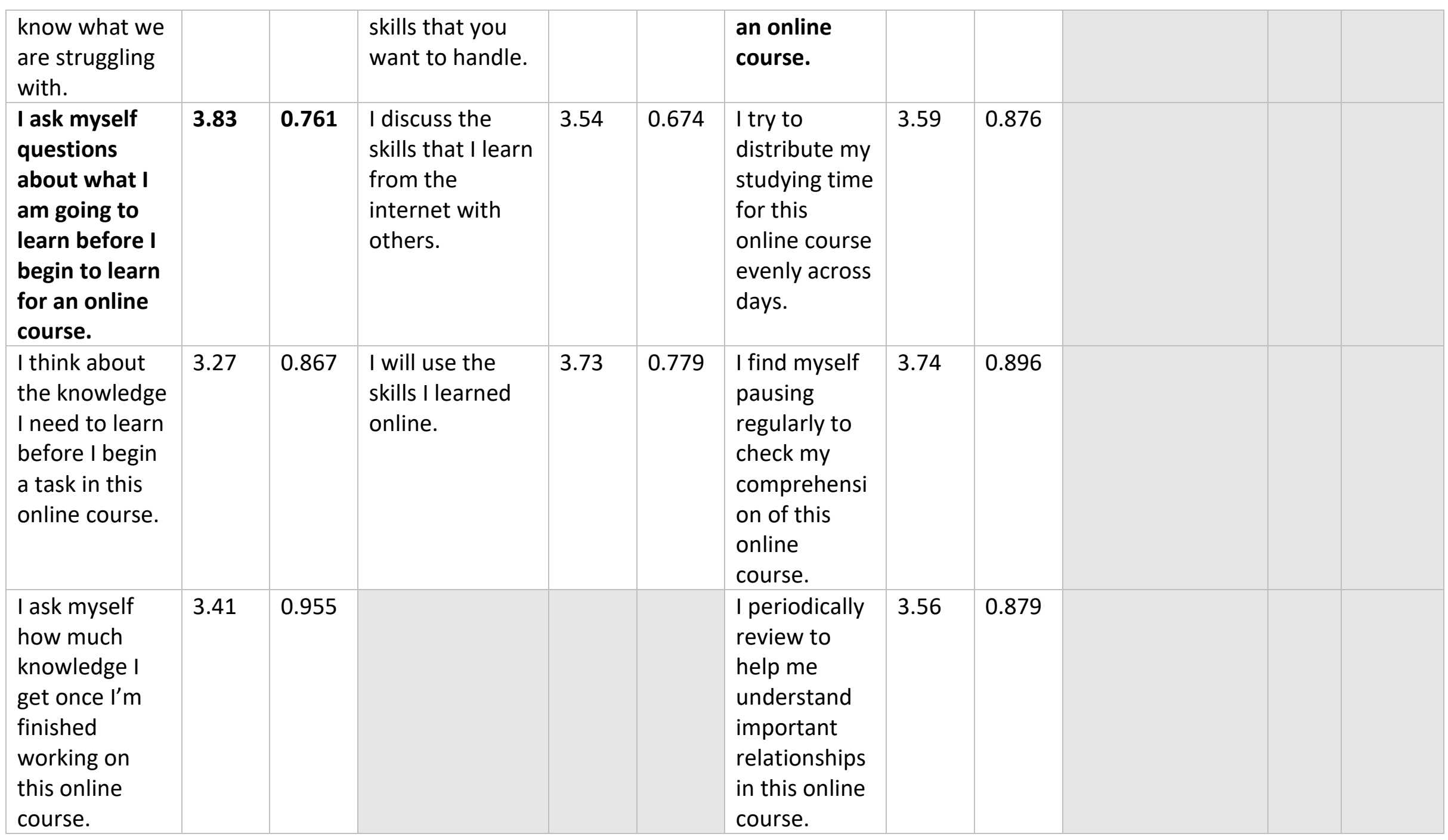


INTERNATIONAL JOURNAL OF ACADEMIC RESEARCH IN PROGRESSIVE EDUCATION AND DEVELOPMENT

Vol. 11, No. 1, 2022, E-ISSN: 2226-6348 @ 2022 HRMARS

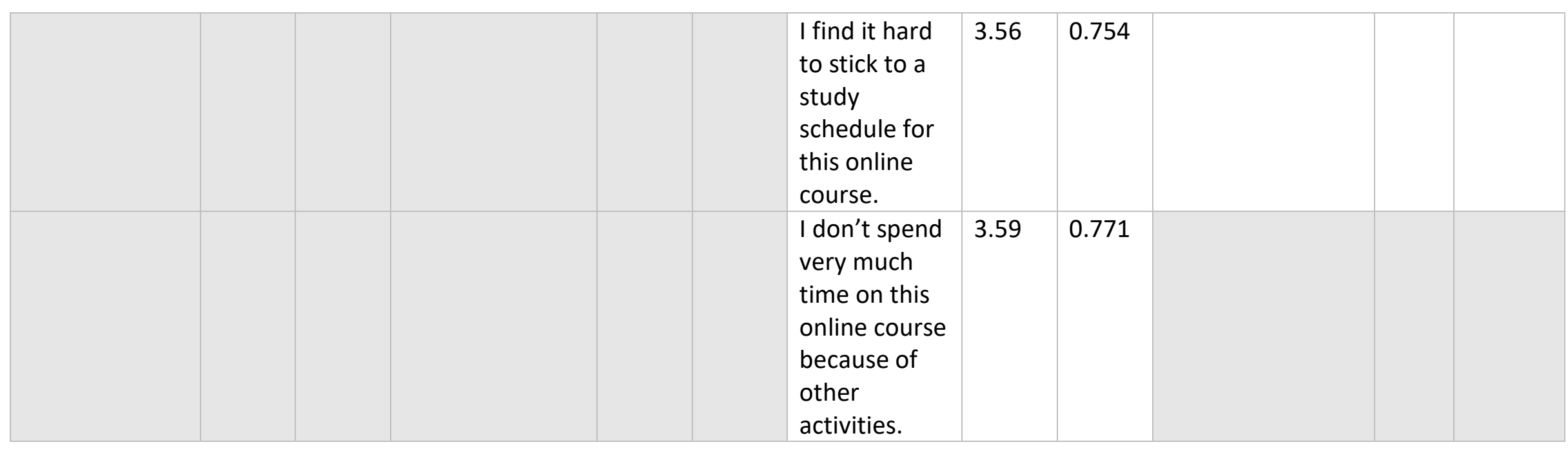


DEVELOPMENT

Vol. 11, No. 1, 2022, E-ISSN: 2226-6348 @ 2022 HRMARS

\section{Correlation Analysis}

The data collected was analyzed using Bivariate Pearson's Correlation. The results were shown in Table 4. Only knowledge was found significant in the online education environment. Hence, the values of other variables are unrelated.

Table 5: Correlational Analysis Result of Studied Variables $(n=70)$

\begin{tabular}{|c|c|c|c|c|c|}
\hline & & Knowledge & Skills & Attitude & $\begin{array}{c}\text { Online } \\
\text { Education } \\
\text { Environment }\end{array}$ \\
\hline \multirow[t]{2}{*}{ Knowledge } & $\begin{array}{l}\text { Pearson } \\
\text { Correlation }\end{array}$ & 1 & .061 & -0.046 & $.017^{*}$ \\
\hline & Sig. (2-tailed) & & .616 & .702 & .890 \\
\hline \multirow[t]{2}{*}{ Skills } & $\begin{array}{l}\text { Pearson } \\
\text { Correlation }\end{array}$ & .061 & 1 & -.004 & .124 \\
\hline & Sig. (2-tailed) & .616 & & .972 & .305 \\
\hline \multirow[t]{2}{*}{ Attitude } & $\begin{array}{l}\text { Pearson } \\
\text { Correlation }\end{array}$ & -0.046 & -.004 & 1 & .065 \\
\hline & Sig. (2-tailed) & .702 & .972 & & .595 \\
\hline $\begin{array}{l}\text { Online } \\
\text { Education }\end{array}$ & $\begin{array}{l}\text { Pearson } \\
\text { Correlation }\end{array}$ & $.017^{*}$ & .124 & .065 & 1 \\
\hline Environment & Sig. (2-tailed) & .890 & .305 & .595 & \\
\hline
\end{tabular}

*significant at $\mathrm{p}<0.05$

\section{Discussion}

In recent years, there has been an increasing interest in the topic of online learning. Notably, researchers have studied the effect of online learning on numerous aspects, for example, teacher competency (Dhawan, 2020; Kaendler et al., 2015; Low et al., 2016; Omar et al., 2020), student competency (Kraft, 2019; Peklaj, 2019) and online learning satisfaction (Shen et al., 2013; Zhang \& Lin, 2020). Despite many arguments aligning online learning with myriad teaching and learning milieu, far too little attention has been paid to technical and vocation stream, acquiring more involvement for students with hands-on and practical training. Few researchers indicated vocational education in an online learning environment however emphases have been given on learning management system (Rabiman et al., 2020), blended learning (Dewi et al., 2018) and learning assessment (Hashim et al., 2019). Although the above investigation examined the TVET as the focus of the study, only a few references describe the effect of online learning especially in TVET, for instance developing digital skills and competency (Brolpito, 2018), digital literacy (Patmanthara, \& Hidayat, 2018) and augmented reality (Acosta et al., 2019). All the aforementioned issues related to previous literatures were the motivation behind the present study.

The findings provide evidence based on the highest means of competency elements from three major competency aspects, knowledge, skills, and attitude. The researcher described 
student responses on selected items "I ask myself questions about what I am going to learn before I begin to learn for an online course, "I always look up the skills that I want to learn on the Internet, and "I manage to keep working on my task in the online course until I finish", indicating the motivation, persistence, curiosity, and self-learning are the comprehensive attributes to empower online learning in TVET stream. Consistent with Shen, Cho, Tsai, and Marra (2013); Zhang and Lin (2020), the researcher found that the competency items as depicted in three factors: knowledge, skills, and attitude contributed to learning satisfaction as a whole. Ideally, the online learning environment propagates learning satisfaction if the aforementioned factors being considered in the TVET teaching and learning ecosystem.

The finding of this current study has a mixed finding from previous results on attitudes and learning or cognitive style (Daniel, 1999; Day et al., 1998; Freeman, 1995; Oxford, Park-Oh, Ito \& Sumrall, 1993). It is interesting to note, however, only knowledge was significantly correlating with online learning environment. In contrast, our findings revealed that the values of skill and attitudes variables did not point towards any relationship between the independent variables and dependent variables which trigger future study on selected variables in different research contexts and methodologies. Among plausible explanations for these findings is that the TVET program's nature which is more of hands-on mastery and practical skills contradictory with the online learning environment where student engagement is more of digitalization, use of online applications and software, and utilization of computer-supported by internet technology.

The conventional teaching and learning model may not be viable for the next couple of years to the pandemic COVID-19 sequentially be replaced with online learning such as gaining the preferable and popular approach. TVET field inherits students existent physically to learn via tangible evidence, synchronous learning, and ongoing feedback and observation, which are quite hurdles to be implied in the online learning environment. The progressive and pragmatic approach of the TVET stream also becomes the premise in assessment where lifelong learning is the pillar of this particular field. In contrast, the TVET stream will struggle to deliver the learning content, especially on practical training where applying motor skills is pivotal. Panigrahi et al (2018) discussed the strategies and challenges for online learning where it is most common for the educator to malign the flexibility of online learning without grasping the notion of the extent of students meaning learning. Indeed, the individual anticipation such as the perceived usefulness, perceived ease of use, perceived enjoyment, performance expectancy, effort expectancy, and the external influences such as subjective norm, social norms, surrounding conditions, national culture, social network characteristic are important factors in learning (Panigrahi et al., 2018). The findings supported the notion that technology use is the experiences of the individuals in the technology, such as satisfaction, confirmation, self-efficacy, flow, trust, intention, sense of belongingness, immersion, qualities, which are the greatest predictors towards meaningful online learning experience.

TVET educator who described as the frontier of TVET education aboard a difficult situation when COVID-19 strikes the world. Today, the education system perceived a major impact and imparts the process of education in innumerable ways. Innovation and change in the pedagogical are much needed where some educators who have a long-standing approach in teaching refuse to change (Dhawan, 2020). This occurs the same way as TVET educators. Adopting and adapting the use of technology in teaching becomes a huge challenge for TVET 
educators and inevitable. Change in the TVET system's conational way is far beyond the imagination. Although numerous online courses for job and skill training are offered to allow professionals to increase their competency and upgrade their skills (Oncu \& Cakir, 2011), such as Coursera and MOOCs, TVET educators require time to make the change and be competent before inheriting those competencies to TVET learners. Thus, the idealistic of online learning, especially for the TVET system, seems unrealistic at the moment.

Moreover, the foreground on competency-based education (CBE) in the TVET stream sounds impeccable through the accreditation process by the Malaysian TVET council. Nevertheless, the online learning environment for TVET learners undoubtedly able to achieve learning attainment as projected by the CBE document. Capturing the required competencies such as demonstrating higher-level skills, such as critical thinking, at levels comparable to those enrolled in more traditional programs are significant (Mayeshiba et al., 2018). Equally important for TVET learners, such competency attributes are difficult to be transmitted without clear instruction for educators and continuous training on mastering specific skills.

TVET learners who rely voraciously on practical skills teaching modes, though discriminately, requires necessary gain in the upskilling and reskilling environment through conventional learning approaches. Nevertheless, the practical based teaching are replete with online teaching forms that included tutorial videos, websites, and online courses; leaving the core element of the tangible learning experience of using technology, tools, and apparatuses, bringing the momentarily learning experience worthless. Effective communication, technology, learning, and feedback strategies and the corresponding demands on teacher and learner competencies are higher (Roddy et al., 2017) yet, missing in TVET teaching and learning approaches. Roddy et al (2017) added that the presence of instructors remains a significant aspect for all models in an online study where an intensive online environment should be emphasized and retain engagement; undoubtedly, tremendously difficult to be implemented in TVET.

It is recommended that further research be undertaken in the following areas; (a) further experimental investigation through longitudinal approach is suggested to indicate the current competency attributes from intervention process, (b) gaining more sample size for the study and obtain wider population, (c) through qualitative inquiry by adopting document analysis of existing CBE application; indicating the current competency be trained in the TVET system, and (d) complementarily with digital competency framework to synchronize the wide application of online learning approaches in TVET.

\section{Conclusion}

Although there is great potential for online learning in TVET, there seems to be a great laxity in the implementation. Understandably, TVET institutions in developing countries are mainly aggravated by limited funding opportunities. Even if online learning is the right direction to move towards for TVET institutions in developing countries, TVET stakeholders should come together and work towards a common agenda of embedding online learning within the TVET system. There should also be a gradual investment in online learning in wider scopes of TVET institutions to increase prospects of future growth and development of the human capital of such nations. 
DEVELOPMENT

Vol. 11, No. 1, 2022, E-ISSN: 2226-6348 @ 2022 HRMARS

\section{Acknowledgments}

Special thanks to Innovative Learning Sciences Research Centre of Excellence (INNOVATE), Publication and Citation Unit (PACU) and Faculty of Educational Studies, Universiti Putra Malaysia for assistance and financial support for this study.

\section{References}

Acosta, J. L. B., Navarro, S. M. B., Gesa, R. F., \& Kinshuk, K. (2019). Framework for designing motivational augmented reality applications in vocational education and training. Australasian Journal of Educational Technology, 35(3).

Berry, D., \& Broadbent, D. (1988). Interactive tasks and the implicit-explicit distinction. The British Journal of Psychology, 79(2), 251-272. https://doi.org/10.1111/j.20448295.1988.tb02286.x

Bilsland, C., Nagy, H., \& Smith, P. (2020). Virtual internships and work-integrated learning in hospitality and tourism in a post-COVID-19 world. International Journal of WorkIntegrated Learning, 21(4), 425-437.

Boyatzis, R. (1982). The competent manager : a model for effective performance . Wiley.

Brolpito, A. (2018). Digital Skills and Competence, and Digital and Online Learning. European Training Foundation.

Carlson, R., Sullivan, M., \& Schneider, W. (1989). Practice and working memory effects in building procedural skill. Journal of Experimental Psychology. Learning, Memory, and Cognition, 15(3), 517-526. https://doi.org/10.1037//0278-7393.15.3.517

Carlson, R., \& Yaure, R. (1990). Practice schedules and the use of component skills in problem solving. Journal of Experimental Psychology. Learning, Memory, and Cognition, 16(3), 484-496. https://doi.org/10.1037//0278-7393.16.3.484

Chase, W. G., \& Ericsson, K. A. (1982). Skill and working memory. In Psychology of learning and motivation (Vol. 16, pp. 1-58). Academic Press

Collin, A. (1997). Learning and development. Humana Resource Management: a contemporary perspective London, Pitman.

Creswell, J., \& Creswell, J. (2018). Research design : qualitative, quantitative, and mixed methods approaches (Fifth edition.). SAGE Publications, Inc.

Daniel, J. (1999). Open learning and/or distance education: which one, for what purpose. Higher education through open and distance learning, 292-298.

Day, T., Raven, M., \& Newman, M. (1998). The Effects Of World Wide Web Instruction And Traditional Instruction And Learning Styles On Achievement And Change In Student Attitudes In A Technical Writing In An Agricommunication Course. Journal of Agricultural Education, 39(4), 65-75. https://doi.org/10.5032/jae.1998.04065

Dewi, K. C., Ciptayani, P. I., \& Surjono, H. D. (2018). Critical success factor for implementing vocational blended learning. In Journal of Physics: Conference Series (Vol. 953, No. 1, p. 012086). IOP Publishing.

Dewi, K. C., Ciptayani, P. I., \& Surjono, H. D. (2018). Modeling Vocational Blended Learning Based on Digital Learning Now Framework. Turkish Online Journal of Educational Technology-TOJET, 17(2), 89-96.

Dhawan, S. (2020). Online learning: A panacea in the time of COVID-19 crisis. Journal of Educational Technology Systems, 49(1), 5-22.

Dlamini, P. I. (2015). The role of Majuba Technical and Vocational Education and Training College programmes in addressing industrial skills shortages in Newcastle and Amajuba District (Doctoral dissertation). 
Freeman, M. (1995). Peer Assessment by Groups of Group Work. Assessment and Evaluation in Higher Education, 20(3), 289-300. https://doi.org/10.1080/0260293950200305

Fuchs, M. (2016). Worldwide knowledge?: global firms, local labour and the region. Routledge.

Grdic, T., Celhasic, D., \& Özer, L. (2008). The traditional vs. the online market: A study of consumer behaviour and consumer preferences in the purchase of high-involvement products (Dissertation). Retrieved from http://urn.kb.se/resolve?urn=urn:nbn:se:hj:diva-115

Hashim, S., Utami, P., Rahman, M. H. A., Jumaat, N. F., \& Phon, D. N. E. (2019). Knowledge Construction Process in an Open Learning System Among Technical and Vocational Education and Training (TVET) Practitioners. Journal of Technical Education and Training, 11(1).

James, W. B., \& Gardner, D. L. (1995). Learning styles: Implications for distance learning. New directions for adult and continuing education, 1995(67), 19-31.

Keller, J. M. (1979). Motivation and Instructional Design: A Theoretical Perspective. Journal of Instructional Development, 2(4), 26-34. https://doi.org/10.1007/BF02904345

Kelman, H. C. (1974). Attitudes are alive and well and gainfully employed in the sphere of action. American psychologist, 29(5), 310.

Klieme, E. (2004). Assessment of cross-curricular problem-solving competencies. Comparing learning outcomes. International assessments and education policy, 81-107.

Kock, H., \& Ellström, P. (2011). Formal and integrated strategies for competence development in SMEs.Journal of European Industrial Training, 35(1), 71-88. https://doi.org/10.1108/03090591111095745

Kotler, P. (2005). The Role Played by the Broadening of Marketing Movement in the History of Marketing Thought. Journal of Public Policy \& Marketing, 24(1), 114-116. https://doi.org/10.1509/jppm.24.1.114.63903

Ladipo, M. K., Akhuemonkhan, I. A., \& Raimi, L. (2013). Technical Vocational Education and Training (TVET) As a Mechanism for Sustainable Development in Nigeria (SD): Potentials, Challenges and Policy Prescriptions. TVET for Sustainable Development in Africa" Held in Banjul, The Gambia from 2 nd To 8 th June 2013 at The Paradise Suits Hotel, 12.

Lavery, J. (1962). Retention of simple motor skills as a function of type of knowledge of results. Canadian Journal of Psychology, 16(4), 300-311. https://doi.org/10.1037/h0083257

Lintern, G., \& Gopher, D. (1978). Adaptive training of perceptual-motor skills: issues, results, and future directions. International Journal of Man-Machine Studies, 10(5), 521-551. https://doi.org/10.1016/S0020-7373(78)80018-2

Logie, R. H. (1989). Characteristics of visual short-term memory. European Journal of Cognitive Psychology, 1(4), 275-284.

Mathur, S. R., Kavale, K. A., Quinn, M. M., Forness, S. R., \& Rutherford, R. B. (1998). Social Skills Interventions with Students with Emotional and Behavioral Problems: A Quantitative Synthesis of Single-Subject Research. Behavioral Disorders, 23(3), 193201. https://doi.org/10.1177/019874299802300306

Mayeshiba, M., Jansen, K. R., \& Mihlbauer, L. (2018). An evaluation of critical thinking in competency-based and traditional online learning environments. Online Learning, 22(2), 77-89. doi: 10.24059/olj.v22i2.1365 
McKeithen, K., Reitman, J., Rueter, H., \& Hirtle, S. (1981). Knowledge organization and skill differences in computer programmers. Cognitive Psychology, 13(3), 307-325. https://doi.org/10.1016/0010-0285(81)90012-8

Oxford, R., Park-Oh, Y., Ito, S., \& Sumrall, M. (1993). Learning a language by satellite television: what influences student achievement? System (Linköping), 21(1), 31-48. https://doi.org/10.1016/0346-251X(93)90005-2

Omar, M. K., Zahar, F. N., \& Rashid, A. M. (2020). Knowledge, skills, and attitudes as predictors in determining teachers' competency in Malaysian TVET institutions. Universal Journal of Educational Research, 8(3C), 95-104.

Oncu, S., \& Cakir, H. (2011). Research in online learning environments: Priorities and methodologies. Computer \& Education, 57(1), 1098-1108

Panigrahi, R., Srivastava, P. R., \& Sharma, D. (2018). Online learning: Adoption, continuance, and learning outcome-A review of literature. International Journal of Information Management, 43, 1-14.

Patmanthara, S., \& Hidayat, W. N. (2018, June). Improving vocational high school students digital literacy skill through blended learning model. In Journal of Physics: Conference Series (Vol. 1028, No. 1, p. 012076). IOP Publishing.

Rabiman, R., Nurtanto, M., \& Kholifah, N. (2020). Design and Development E-Learning System by Learning Management System (LMS) in Vocational Education. Online Submission, 9(1), 1059-1063.

Roberts, T. G., \& Dyer, J. E. (2005). The relationship of self-efficacy, motivation, and critical thinking disposition to achievement and attitudes when an illustrated web lecture is used in an online learning environment. Journal of Agricultural Education, 46(2), 12-23.

Robotham, D., \& Jubb, R. (1996). Competences: measuring the unmeasurable. Management Development Review, 9(5), 25-29. https://doi.org/10.1108/09622519610131545

Roddy, C., Amiet, D. L., Chung, J., Holt, C., Shaw, L., McKenzie, S., ... \& Mundy, M. E. (2017, November). Applying best practice online learning, teaching, and support to intensive online environments: an integrative review. In Frontiers in Education (Vol. 2, p. 59). Frontiers.

Salthouse, T. (1986). Effects of practice on a typing-like keying task. Acta Psychologica, 62(2), 189-198. https://doi.org/10.1016/0001-6918(86)90068-5

Schunk, D. (2000). Coming to Terms with Motivation Constructs. Contemporary Educational Psychology, 25(1), 116-119. https://doi.org/10.1006/ceps.1999.1018

Shen, D., Cho, M. H., Tsai, C. L., \& Marra, R. (2013). Unpacking online learning experiences: Online learning self-efficacy and learning satisfaction. The Internet and Higher Education, 19, 10-17.

UNESCO-UNEVOC. (2021). New qualifications and competencies for future-oriented TVET. Retrieved January $28^{\text {th }}, 2022$ from

https://unevoc.unesco.org/pub/new_qualifications_and_competencies_for_futureoriented_tvet_-_vol_1_.pdf

Welford, A. T. (1968). Fundamentals of skill. London: Methuen

Welford, A. (1976). Skilled performance : perceptual and motor skills . Scott, Foresman.

Yonghak, L. (2009). Competencies needed by Korean HRD master's graduates: A comparison between the ASTD WLP competency model and the Korean study. Human Resource Development Quarterly, 20(1), 107-133. https://doi.org/10.1002/hrdq.20010 
INTERNATIONAL JOURNAL OF ACADEMIC RESEARCH IN PROGRESSIVE EDUCATION AND DEVELOPMENT

Vol. 11, No. 1, 2022, E-ISSN: 2226-6348 @ 2022 HRMARS

Zhang, Y., \& Lin, C. H. (2020). Student interaction and the role of the teacher in a state virtual high school: what predicts online learning satisfaction?. Technology, Pedagogy and Education, 29(1), 57-71. 